\title{
Development and commissioning of a test system based on a TEM cell for RF exposure
}

\author{
Daniele Desideri, Alvise Maschio*
}

\begin{abstract}
In the development of a low-cost two-port TEM cell, a new analytical model of the capacitance of the terminations has been performed. The model has been verified by calculating the termination capacitance by means of a commercial 3D code. A TEM cell modified in accordance with the obtained results has been tested, with reference to the voltage standing wave ratio (VSWR) parameter, and the obtained improvements on VSWR versus frequency are reported. The TEM cell is the principal part of a test system for RF exposure (up to $230 \mathrm{MHz}$ ), including signal generator, power amplifier, dual directional coupler, $50 \Omega$ load attenuator and $1 \mathrm{GHz}$ bandwidth oscilloscope, whose commissioning has been performed. A numerical analysis has been performed also for calculating the stationary electric field in the TEM cell. Experimental measurements of electric field inside the TEM cell, by means of an electric field meter (100 kHz - $6 \mathrm{GHz}$ broadband) were done, and the results are in good agreement with the numerical data.
\end{abstract}

Keywords TEM cell, VSWR measurements, Electric field measurements, Biological RF test system.

\section{Desenvolvimento e comissionamento de um sistema de teste baseado em célula TEM para exposição $R F$}

Resumo Este trabalho descreve o desenvolvimento de um célula TEM de baixo custo com duas portas. Um novo modelo analítico para as capacitâncias de suas terminações é também demonstrado. O modelo foi avaliado calculando-se a capacitância da terminação por meio de um código de análises de elementos finitos $3 D$ comercial. Uma célula TEM modificada de acordo com os resultados foi testada, e as melhorias obtidas em termos da taxa de onda estacionária de tensão (TOET) em relação à frequência são descritas. A célula TEM é a parte principal de um sistema de teste para exposição de RF (até $230 \mathrm{MHz}$ ), que inclui ainda gerador de sinais, amplificador de potência, acoplador direcional dual, atenuador de carga de $50 \Omega$ e um osciloscópio com largura de banda $1 \mathrm{GHz}$. A análise numérica foi também realizada para o cálculo do campo elétrico estacionário na célula TEM. Um medidor de campo elétrico (100 kHz - $6 \mathrm{GHz}$ ) foi utilizado para medições experimentais no interior da célula TEM, e os resultados obtidos mostraram ser concordantes com os dados numéricos.

Palavras-chave Célula TEM, Medições de TOET, Medições de campo elétrico, Sistema de teste RF. 


\section{Introduction}

TEM cell is a way of producing a plane electromagnetic wave with known characteristics and good accuracy in a shielded environment; moreover high electric field values are obtained with a low cost system. Originally proposed in 1974 (Crawford, 1974), it is now largely used for calibration of RF probes (Italian guide CEI, 2001), and in the electromagnetic compatibility field (International..., 2003). Biomedical applications are important too, both for thermal and non-thermal effects investigation (Dlugosz and Trzaska, 2006; Popovic et al., 1998; Racuciu et al., 2007; Wu et al., 2007).

A rectangular coaxial two-port TEM cell for RF analyses has been designed and built at the Department of Electrical Engineering of the University of Padova; the design criteria and the results of preliminary tests were reported in (Desideri et al., 2007; Desideri and Maschio, 2008). The critical effects of the shape of the septum terminations were put in evidence by the preliminary tests, so that a very careful evaluation of the capacitance of the terminations, which is the fundamental parameter in determining the characteristic impedance of this part of the TEM cell, has been performed.

In this paper the analytical model used for the evaluation of the termination capacitance is presented. The results of the calculations performed with a commercial 3D code for the validation of the analytical calculations and the evaluation of the pattern of the electric field inside the TEM cell are also presented. Further, the procedure for the commissioning of the test system is reported, and the main experimental results in terms of Voltage Standing Wave Ratio (VSWR) and electric field pattern are presented. Final remarks and conclusions are given in the end.

\section{Methods}

\section{Termination capacitance: analytical model}

The TEM cell was designed for a maximum size of equipment under test (EUT) of about $270 \times 220 \times 60 \mathrm{~mm}$ (Desideri et al., 2007). The planned highest test frequency with only a TEM mode was $230 \mathrm{MHz}$. A schematic outline of the TEM cell with the indication of the reference axes is given in Figure 1. The dimensions of the central part of the TEM cell are given in the following: cell width $a=450 \mathrm{~mm}$; septum width $w=364 \mathrm{~mm}$; distance between the septum and the floor $h=179.25 \mathrm{~mm}$; length $L=462 \mathrm{~mm}$, giving a maximum EUT of $0.6 L \times 0.6 w \times 0.33 h$ (Standard IEC 61000-4-20). The septum is in brass, $1.5 \mathrm{~mm}$ thick, with a final part in copper, $0.6 \mathrm{~mm}$ thick.

The quality of the TEM cell is related to the VSWR, which is defined as:

$$
\operatorname{VSWR}=\frac{1+|\Gamma|}{1-|\Gamma|}
$$

where $|\Gamma|$ is the ratio between the amplitudes of the reflected voltage wave and the incident voltage wave respectively: a value of VSWR not greater than 1.2 can be considered as good.

An improved version has been developed in order to achieve a value of VSWR not greater than 1.2 in
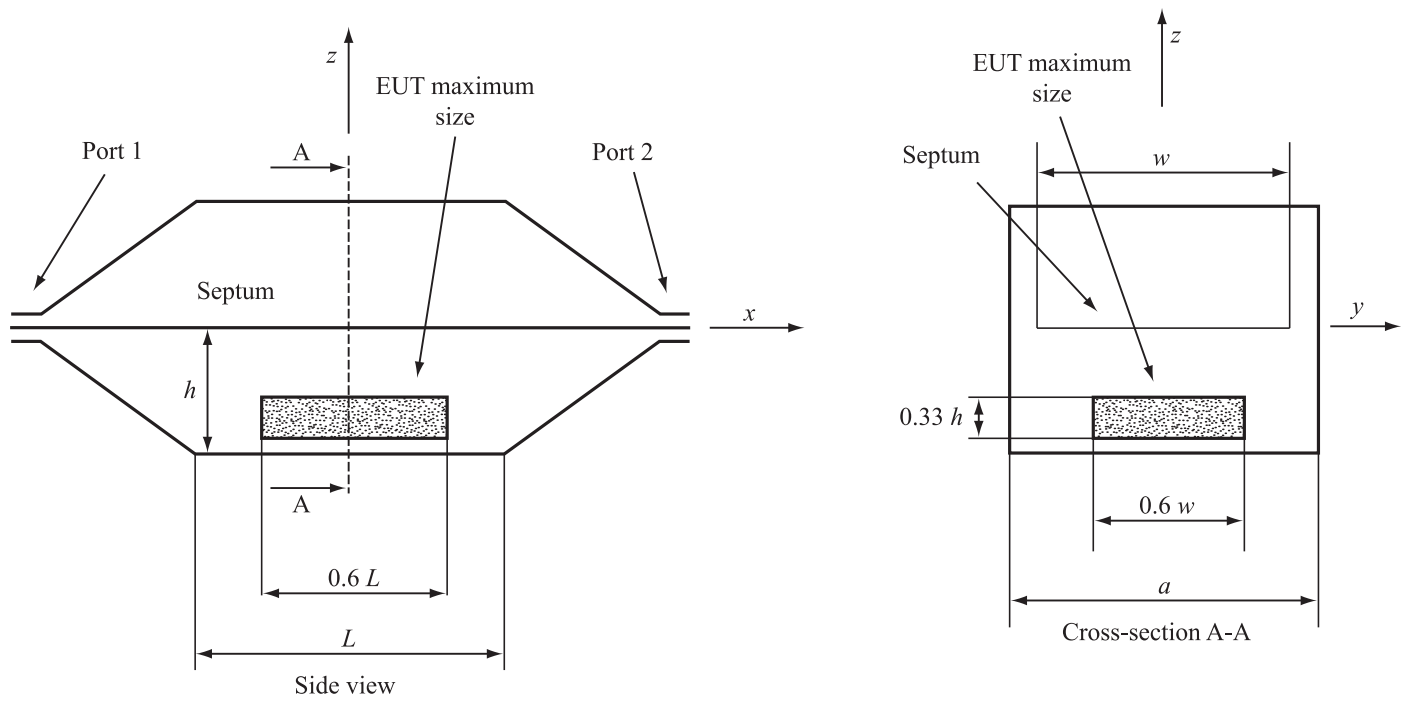

Figure 1. Side view and cross-section of the TEM cell outline with reference axes. 
the largest possible frequency range of the TEM cell. The analysis has been focused on the terminations. A detailed analytical evaluation of the capacitances of the terminations has been performed, considering both a distributed capacitance along the termination length and a concentrated frontal edge capacitance at the end of the termination, in order to obtain a characteristic impedance, in the average, equal to the value of the central part $(50 \Omega)$.

\section{Distributed termination capacitance}

The terminations of the septum have been well centered and precisely filed to the correct value according to the formula of the capacitance per unit length $\left(C_{\ell}\right)$ (Cruzan and Garver, 1964):

$$
\begin{aligned}
& C_{\ell}=4 \varepsilon_{0} \frac{2}{\pi} \ln \left(1+\operatorname{coth} \frac{\pi g^{*}}{2 h^{*}+b^{*}}\right)+ \\
& 2 \varepsilon_{0} \frac{w^{*}}{h^{*}}+2 \varepsilon_{0} \frac{b^{*}}{g^{*}}=C_{\ell 1}+C_{\ell 2}+C_{\ell 3}
\end{aligned}
$$

where the quantities $b^{*}, h^{*}, w^{*}, g^{*}$ are shown in Figure 2, which shows the rectangular cross-section of the terminations. The formula is the sum of three terms. The term $C_{\ell 2}$ is the contribution due to the central part and the term $C_{\ell 3}$ is the side contribution due to the septum thickness: both derive from the parallel plate capacitance equation. The term $C_{\ell 1}$ instead is related to the edge effect, which is not included in the other two terms. In this TEM cell, with $b^{*}=0.6 \mathrm{~mm}$, $h^{*}=17.7 \mathrm{~mm}, w^{*}=35.6 \mathrm{~mm}, g^{*}=4.7 \mathrm{~mm}, C_{\ell}$ is equal to $66.6 \mathrm{pF} / \mathrm{m}$.

\section{Frontal edge capacitance}

A rectangular septum termination is assumed in Figure 3. A central side view of the septum termination is reported in Figure 3a. The configuration is similar to the one depicted in Figure 2 and therefore (3), derived from (2), has been used for the estimation of the frontal edge capacitance:

$$
C=\left[2 \varepsilon_{0} \frac{2}{\pi} \ln \left(1+\operatorname{coth} \frac{\pi d}{2 h^{*}+b^{*}}\right)+\varepsilon_{0} \frac{b^{*}}{d}\right] \cdot w^{*}
$$

where the quantities $b^{*}, d, h^{*}$ and $w^{*}$ are shown in Figure 3. The values of $b^{*}, h^{*}$ and $w^{*}$ are given below.

This frontal edge capacitance has been divided by the distance $d$, and the result has been treated as a capacitance per unit length: the hypothesis was that, taking its value equal to the $C_{\ell}$ of (1), a $50 \Omega$ characteristic impedance could be obtained. With $d$ equal to $1 \mathrm{~mm}$ and $7 \mathrm{~mm}$ respectively, and

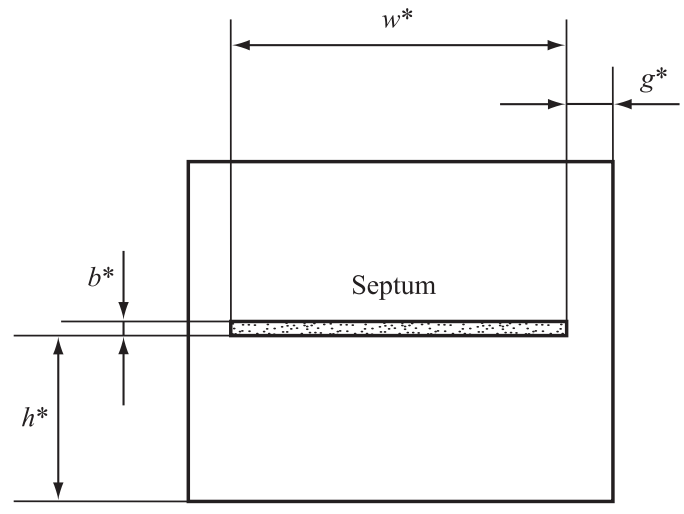

Figure 2. Rectangular cross-section of the terminations.
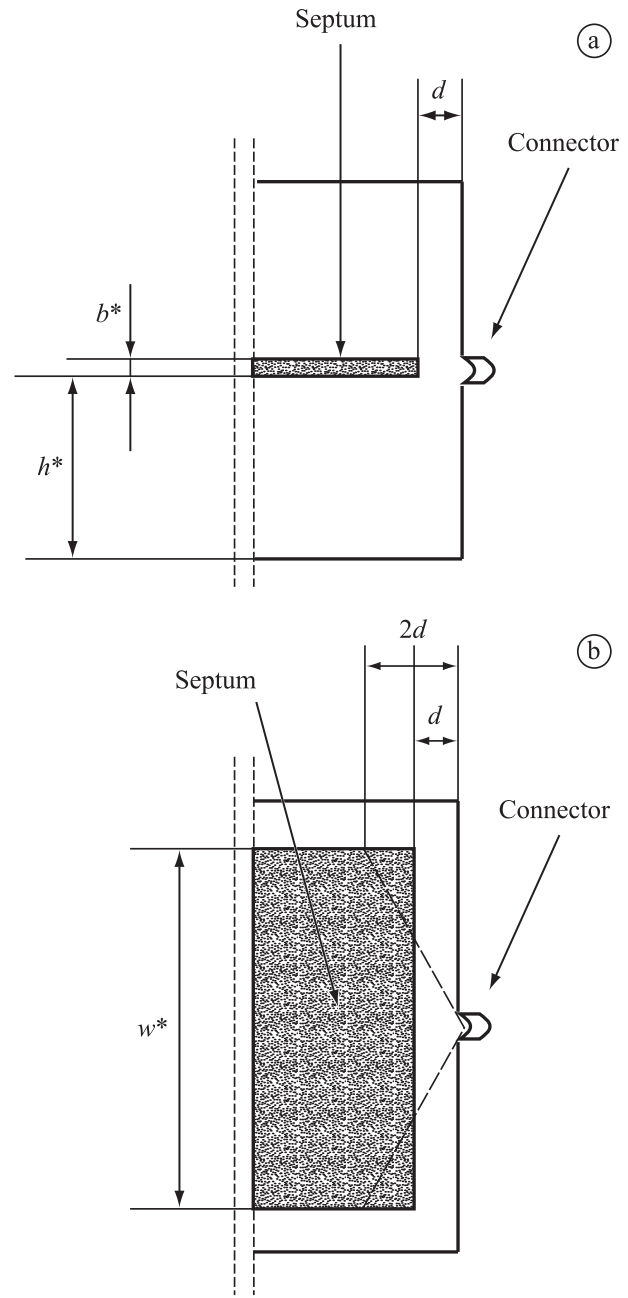

Figure 3. TEM cell: a) central side view, and b) central plan view.

the other parameters as previously taken, frontal edge capacitances $C$ equals to $1.20 \mathrm{pF}$ and $0.45 \mathrm{pF}$ respectively were found. It is noticed that the ratio of $C / d$, with $d$ equal to $7 \mathrm{~mm}$, is almost equal to 
the $C_{\ell}$ previously reported. In addition, in order to obtain a gradual connection between the septum and the connector, a linear termination (dashed line in Figure $3 \mathrm{~b}$ ), has been adopted. The hypothesis was that this triangular geometry with height $2 d$ had almost the same capacitance of the rectangular septum termination with distance $d$.

\section{Results}

\section{TEM cell: DC numerical analysis}

A 3D finite element commercial code (Maxwell ${ }^{\mathbb{R}}$ 3D) has been used in stationary conditions for a comparison with (2) and for the evaluation of the stationary electric field inside the TEM cell.

\section{Frontal edge capacitance: numerical analysis}

A first numerical analysis has been performed considering only the terminations of the TEM cell, joined together, and evaluating the capacitance between the septum and the outer conductor. In this case the total capacitance value is due to the contribution of the two frontal edge plus the two distributed termination capacitances.

At first, the geometry depicted in Figure 3b (continuous line), and including the septum transition between brass and copper, has been numerically analyzed, in two cases: with $d$ equal to $1 \mathrm{~mm}$ (and length of $124 \mathrm{~mm}$ ) and $d$ equal to $7 \mathrm{~mm}$ (and length of $112 \mathrm{~mm}$ ). The resulting capacitances were of $10.7 \mathrm{pF}$ and $8.4 \mathrm{pF}$ respectively, in very good agreement with the values obtained by the analytical formulas.

Then the numerical analysis of the geometry depicted in Figure 3b (dashed line - gradual connection) has been considered (including the hole for the connector) and the result compared with the equivalent rectangular septum termination, with the same area. The triangular geometry with height $2 d$ has almost the same capacitance of the rectangular septum termination with distance $d$ (Figure 3).

\section{D numerical analysis of the TEM cell}

The same code has been used for the numerical calculation of the electric field with the complete geometry of the TEM cell. About sixty thousands tetrahedra have been used in the simulation and Figures $4 \mathrm{a}, \mathrm{b}$ show some results at $x=0 \mathrm{~mm}$ and $x=90 \mathrm{~mm}$ respectively. The $z$ and $y$ components of the electric field are shown, while the $x$ component has not been reported, being negligible in both cases. The numerical data have been calculated with a voltage of $1 \mathrm{~V}$ between septum and outer conductor.
When $x=0 \mathrm{~mm}$, the module of $z$ component of the electric field is about $10 \%$ higher at $z=-80 \mathrm{~mm}$ than at $z=-150 \mathrm{~mm}$. The numerical data at $x=90 \mathrm{~mm}$ are almost equal to the ones at $x=0 \mathrm{~mm}$ (Figure 4).

\section{Commissioning of the test system}

The test system set-up is shown in Figure 5. A signal generator with a power RF amplifier (35 W nominal output $\mathrm{CW}$ power, $10 \mathrm{kHz}-250 \mathrm{MHz}$ frequency response) is connected to the TEM cell by a dual directional coupler $(10 \mathrm{kHz}-400 \mathrm{MHz}$ frequency

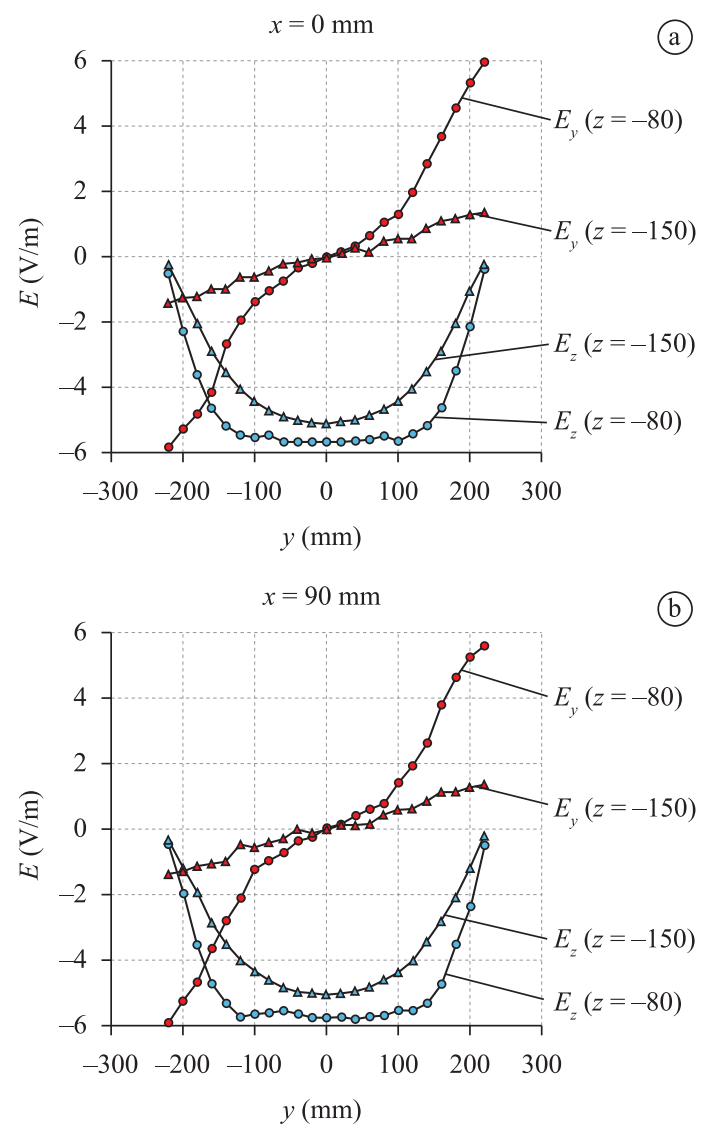

Figure 4. Electric field at a) $x=0 \mathrm{~mm}$, and b) $x=90 \mathrm{~mm}$.

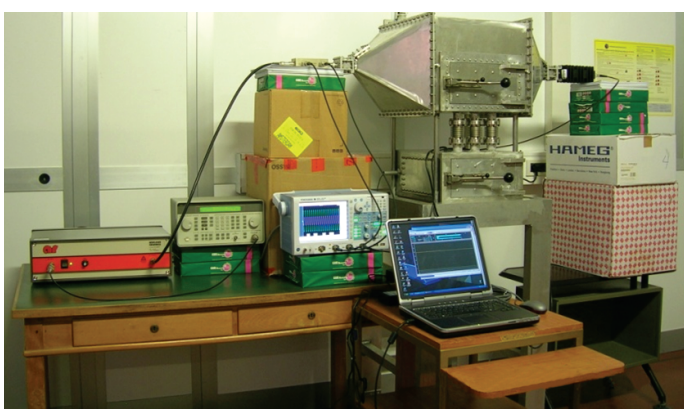

Figure 5. RF test system. 
range). The voltages proportional to the incident and reflected voltage waves are reported on a $1 \mathrm{GHz}$ bandwidth oscilloscope. On the other port of the TEM cell a $50 \Omega$ load attenuator is connected and the voltage signal is shown on the oscilloscope. The frequency range of the test system is $10 \mathrm{kHz}-230 \mathrm{MHz}$. For the measurement of the electric field inside the two-port TEM cell, an electric field probe $(100 \mathrm{kHz}-6 \mathrm{GHz}$ broadband) has been used.

\section{VSWR measurements}

The VSWR has been measured; the values obtained are reported as a function of frequency in Figure 6. The values have been measured with linear terminations (Figure 3b), at different values of $d$. The frequency range, where VSWR is not greater than 1.2, increases with $d$ from $2.5 \mathrm{~mm}$ up to $5 \mathrm{~mm}$; it remains almost constant from 5 to $7 \mathrm{~mm}$. The maximum frequency, with VSWR not greater than 1.2, has been obtained at $177 \mathrm{MHz}$. At the highest frequencies, the best values of VSWR were obtained with $d=7 \mathrm{~mm}$.

\section{Electromagnetic field measurements}

The electric field has been measured in a few positions by means of an electric field meter $(100 \mathrm{kHz}-6 \mathrm{GHz}$ broadband) (Figure 7). The probe has a cubical house $32 \mathrm{~mm}$ side and three sensor-protection caps $43 \mathrm{~mm}$ height. In the following, the nominal measurement point is the barycentre of the cubical housing. The not negligible dimensions of the sensors may give a difference between measured and actual value in the reference measurement point.

The measurements have been done at two frequencies $(50 \mathrm{MHz}$ and $180 \mathrm{MHz}$ ), under the septum at two heights $(z=-150 \mathrm{~mm}$ and $z=-80 \mathrm{~mm})$, at two different sections (the central one, i.e. $x=0$, and at $x=90 \mathrm{~mm})$, and at two values of $y(y=0$ and at a distance of $115 \mathrm{~mm}$ from the lateral sides of the TEM cell).

All the reported values are RMS values, and measurements have been performed keeping a $25 \mathrm{~V}_{\mathrm{RMS}}$ voltage at the $50 \Omega$ load attenuator.

The measured data are in good agreement with the stationary numerical results. As an example, at $x=0, y=0$, the $z$-component of the electric field has been measured equal to $136 \mathrm{~V} / \mathrm{m}(f=50 \mathrm{MHz})$ and $143 \mathrm{~V} / \mathrm{m}(f=180 \mathrm{MHz})$ at $z=-150 \mathrm{~mm}$, while at $z=-80 \mathrm{~mm}$, it resulted equal to $153 \mathrm{~V} / \mathrm{m}$ $(f=50 \mathrm{MHz})$ and $164 \mathrm{~V} / \mathrm{m}(f=180 \mathrm{MHz})$, with corresponding numerical results, scaled at $25 \mathrm{~V}$, of $128 \mathrm{~V} / \mathrm{m}$ at $z=-150 \mathrm{~mm}$ and $142 \mathrm{~V} / \mathrm{m}$ at $z=-80 \mathrm{~mm}$.

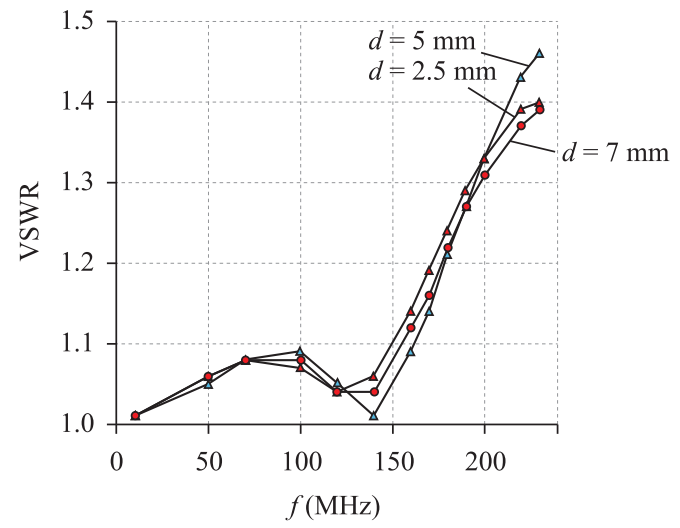

Figure 6. VSWR vs frequency.

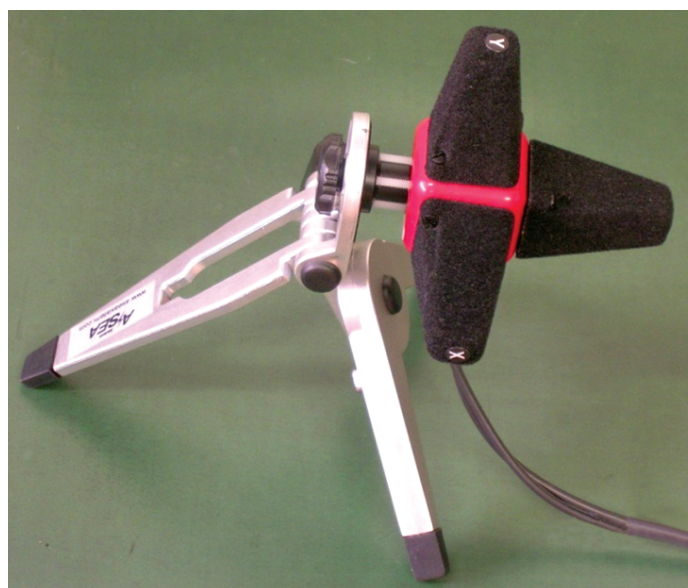

Figure 7. Electromagnetic field test probe.

\section{Conclusions}

The improvement in the design and construction of a low-cost two port TEM cell has been described. The two terminations of the TEM cell have been modified according to a design criterion based on analytical formulas verified with a $3 \mathrm{D}$ computer simulation.

The TEM cell has been included in an RF (up to $230 \mathrm{MHz}$ ) exposure test system, whose commissioning is reported. In particular, values of VSWR not greater than 1.2 have been measured in a large part of the frequency range (up to $177 \mathrm{MHz}$ ). The electric field inside the TEM cell have been calculated by a stationary $3 \mathrm{D}$ code and the numerical results have been experimentally validated. With such a system, studies of the effects, both thermal and non-thermal, on biologic samples can be performed. 


\section{References}

Comitato Elettrotecnico Italiano - CEI. CEI 211-7: guide for the measurement and the evaluation of electromagnetic fields in the frequency range $10 \mathrm{kHz}-300 \mathrm{GHz}$, with reference to the human exposure. Milano: CEI; 2001. In italian.

Crawford ML. Generation of standard EM fields using TEM transmission cells. IEEE Transactions on Electromagnetic Compatibility. 1974; 16(4):189-95. http://dx.doi.org/10.1109/ TEMC.1974.303364

Cruzan OR, Garver RV. Characteristic impedance of rectangular coaxial transmission lines. IEEE Transactions on Microwave Theory and Technique. 1964; 12(5):488-95. http://dx.doi.org/10.1109/TMTT.1964.1125864

Desideri D, Maschio A. Preliminary tests on a low cost two-port TEM cell. Acta Electrotehnica. 2008; (Special Issue):298-301.

Desideri D, Maschio A, Zuccato A. Design of a new low cost two-port TEM cell. In: ISEF'2007: Proceedings of the 13th International Sympium on Electromagnetic Fields in Mechatronics, Electrical and Electronic Engineering, 2007, Prague. ISBN 978-80-01-03784-3. Prague; 2007.
Dlugosz T, Trzaska H. TEM cell in biomedical experiments. In: EMFS: Proceedings of the 4th International Workshop on Biological Effects, 2006, Crete. Crete; 2006. v. 1, p. 89-95.

International Electrotechnical Commission - IEC. Electromagnetic compatibility (EMC) - part 4-20: testing and measurement techniques - emission and immunity testing in transverse electromagnetic (TEM) waveguides. IEC; 2003. IEC 61000-4-20. Geneva.

Popovic M, Hagness SC, Taflove A. Finite-difference timedomain analysis of a complete transverse electromagnetic cell loaded with liquid biological media in culture dishes. IEEE Transactions on Biomedical Engineering. ; 45(8):1067-76, 1998. PMid:9691582. http://dx.doi.org/10.1109/10.704876

Racuciu M, Miclaus S, Creanga DE. Non thermal continuous and modulated RF field effects on vegetal tissue developed from exposed seeds. In: EHE'07: Proceedings of the 2nd International Conference on Electromagnetic Fields, Health and Environment, 2007, Wroclaw. Amsterdam: IOS Press; 2008. p. 142-48.

Wu B-I, Cox FCAI, Kong JA. Experimental methodology for non-thermal effects of electromagnetic radiation on biologics. Journal of Electromagnetic Waves and Applications. 2007; 21(4):533-48. http://dx.doi.org/10.1163/156939307780616829

\section{Authors}

Daniele Desideri, Alvise Maschio 